Ambiente \& Água - An Interdisciplinary Journal of Applied Science
ISSN 1980-993X - doi:10.4136/1980-993X
www.ambi-agua.net
E-mail: ambi-agua@agro.unitau.br

\title{
Análise fenotípica e genotípica de bactérias heterotróficas e fixadoras de nitrogênio em sedimento na bacia do Rio Cuiabá-MT
}

\author{
doi: 10.4136/ambi-agua.1207
}

Received: 30 Sep. 2013; Accepted: 27 Feb. 2014

\author{
Fernanda Viana da Cunha*; Selma Baia Batista \\ Universidade Federal de Mato Grosso (UFMT) - Cuiabá, MT, Brasil \\ Programa de Pós-Graduação em Recursos Hídricos \\ *Autor correspondente: e-mail: fernanda.vianacunha@gmail.com, \\ selfa@bol.com.br
}

\section{RESUMO}

Os sedimentos apresentam-se como um sistema complexo, que são afetados por parâmetros geológicos, hidrodinâmicos, químicos e biológicos, caracterizado por uma interação entre o ambiente sedimentar de cada região. O presente estudo consistiu em caracterizar a diversidade de bactérias heterotróficas totais e fixadores de nitrogênio em sedimentos do rio Cuiabá utilizando técnicas convencionais de microbiologia e de biologia molecular. As amostras de sedimento foram coletadas com periodicidade bimestral, em quatro pontos sendo estes: Cuiabazinho, Passagem da Conceição, Ribeirão dos Cocais e Barão de Melgaço. As amostras foram processadas através de diluições seriadas $\left(10^{-2}\right.$ a $\left.10^{-7}\right) \mathrm{em}$ solução salina $0,85 \%$. Em seguida cultivadas em placa de Petri através da técnica de Spreed Plate, em meio de cultivo Trypic Soy Agar (TSA) para bactérias heterotróficas totais e para bactérias nitrificantes foram utilizados meios seletivos (NFB, JMV e Meio 79) incubadas a $35^{\circ} \mathrm{C}$. Posteriormente as estirpes bacterianas foram reisoladas em Agar Nutriente (AN) a fim de obter cultura pura para análise morfotintorial de Gram. Este teste permitiu verificar que dos 202 isolados bacterianos, 59\% eram bastonetes positivos, sendo que, a maior quantificação bacteriana obtida foi no meio de cultivo TSA, comparado aos outros meios de cultura. $\mathrm{O}$ perfil da comunidade bacteriana apresentou na sua maioria bactérias da família Bacillaceae com $28 \%$, sendo que as mesmas foram utilizadas para a análise molecular por Box-PCR, que apresentou uma riqueza de espécies. Esses resultados indicam a importância de pesquisas sobre diversidade microbiana de sedimentos no Estado de Mato Grosso que utilizam técnicas moleculares.

Palavras-chave: autodepuração, biologia molecular, Box-PCR.

\section{Phenotypic and genotypic analysis of heterotrophic bacteria and nitrogen-fixing in sediment in the basin of the Cuiaba River - MT}

\begin{abstract}
Sediments are complex systems that are affected by geological, hydrodynamic, chemical and biological parameters, as determined by interactions between the sedimentary environments of each region. This study aimed to characterize the diversity of total heterotrophic bacteria and nitrogen fixers in Cuiabá River sediments using conventional
\end{abstract}


techniques of microbiology and molecular biology. Sediment samples were collected bimonthly from four points: Cuiabazinho, Passagem da Conceição, Ribeirão Cocais and Barão de Melgaço. The samples were processed in serial dilutions $\left(10^{-2}\right.$ to $\left.10^{-7}\right)$ in $0.85 \%$ saline solution. They were then cultured in Petri dishes using the Spread Plate technique in the Trypic Soy Agar (TSA) culture medium for total heterotrophic bacteria and selective medium (NFB, JMV and culture median 79) incubated at $35^{\circ} \mathrm{C}$ for nitrifying bacteria. The bacterial strains were then re-isolated on Nutrient Agar (NA) in order to obtain a pure culture for the Gram analysis morphotypes. This test revealed that, of the 202 bacterial isolates, $59 \%$ were positive rods. The largest bacterial count was obtained in the TSA medium, as compared to other means of culture. The profile of the bacterial community showed that most, or $28 \%$, of the bacteria were of the Bacillaceae family and these were used for molecular analysis using Box-PCR, which showed a great diversity of species. These results indicate the importance of microbial diversity research in sediments in Mato Grosso State using molecular techniques.

Keywords: Box-PCR, micro-organisms, self-depuration.

\section{INTRODUÇÃO}

A bacia hidrográfica do rio Cuiabá é tributária do rio Paraguai na parte superior do seu curso, e por isso é considerada uma sub-bacia do rio Paraguai, e está localizada na região Centro-Oeste, englobando parte de Mato Grosso e uma pequena porção do norte de Mato Grosso do Sul. Este também banha a planície Pantaneira, extravasando suas águas para fora do leito no período de cheia, inundando campos e lagoas, contribuindo para formar uma das maiores áreas alagáveis contínuas e também uma das áreas referências em biodiversidade no mundo (Cuiabá, 2005).

É comum verificar no Estado de Mato Grosso a ocupação de cabeceiras de drenagem, principalmente pela agricultura, e a destruição da mata ciliar, situações essas que tornam os recursos hídricos extremamente vulneráveis à contaminação, onde no trecho médio da bacia, altamente urbanizado e industrializado, a principal preocupação é o esgoto doméstico, o qual é responsável por cerca de $80 \%$ da carga orgânica no rio, sendo os restantes $20 \%$ resultantes da atividade agro-industrial (Shinma, 2004; Calheiros, 2008).

Porém, a situação ambiental e hídrica da bacia do rio Cuiabá não resulta apenas da ocupação humana, mas também das próprias características topográficas da região (ANA, 2003), e que pode ser afetada pela sedimentação e alterações dos padrões de ocupação do solo no trecho superior da bacia, uma vez que, os solos arenosos e a topografia acidentada desta região produzem elevadas taxas de sedimentação no rio (Shinma, 2004).

Os ambientes aquáticos são fundamentais para o estabelecimento de muitos grupos de organismos no planeta, sendo assim, a disponibilidade e a boa qualidade destes ambientes é essencial para a manutenção da biodiversidade aquática (Odum, 2007). Segundo Begon et al. (2006), um dos aspectos ecológicos mais impressionantes dos micro-organismos é a sua ubiqüidade, sendo filogeneticamente relacionados, em diferentes proporções, ocorrendo em sincronia no tempo e no espaço, e realizando diversas funções, as bactérias podem representar mais de $90 \%$ desses micro-organismos.

As bactérias heterotróficas desempenham papel importante no estudo dos impactos ambientais, bem como nos sedimentos, sendo considerado um componente importante da comunidade biótica no ecossistema (Gimenes et al., 2010). Estes podem estar associados à produção e o consumo da matéria orgânica e ainda controlar a ciclagem do nitrogênio desempenhando um papel importante nesse processo (Carvalho e Paranhos, 2010). Dessa maneira, o conhecimento da diversidade microbiana é essencial para entender a relação entre os parâmetros ambientais e o funcionamento dos ecossistemas, e isso pode ser possível com o 
avanço da biologia molecular e o uso de novas técnicas no estudo da ecologia desses microorganismos, que permite conhecer sua diversidade e distribuição (Carvalho e Paranhos, 2010).

Como alternativa existem diversos métodos moleculares disponíveis baseados na manipulação dos ácidos nucléicos seja o ácido desoxirribonucléico (DNA) ou o ácido ribonucléico (RNA) que podem ser extraídos de estirpes crescidas em meios de cultura ou até mesmo a partir de amostras diretamente do ambiente, em que se pode citar a PCR, e suas variações, RFLP- PCR, RT-PCR, Nested-PCR, Rep-PCR (REP, ERIC, BOX), PCR em tempo real, e DGGE, Sequenciamento, entre outros (Reis Jr. et al., 2002; Eça, 2004).

O presente estudo consiste em caracterizar a diversidade de bactérias heterotróficas e fixadores de nitrogênio em sedimentos do rio Cuiabá utilizando uma abordagem polifásica de microbiologia convencional e molecular.

\section{MATERIAL E MÉTODOS}

\section{1. Área de estudo}

O estudo foi realizado na bacia do Rio Cuiabá, que se encontra localizada entre as coordenadas geográficas $14^{\circ} 18^{\prime}$ e $17^{\circ} 00^{\prime}$ de latitude Sul e $54^{\circ} 40^{\prime}$ e $56^{\circ} 55^{\prime}$ de longitude Oeste, o Rio Cuiabá, que drena uma área aproximada de $21.730 \mathrm{~km}^{2}$ até a cidade de Cuiabá, sendo este um dos principais afluentes do Rio Paraguai (Cuiabá, 2005).

\subsection{Delineamento amostral}

Foram realizadas seis coletas, sendo a primeira em Julho de 2011 e a última em Maio de 2012, com periodicidade bimestral, contemplando um ciclo anual durante os períodos de seca (maio, julho e setembro) e chuva (novembro, janeiro e março) em quatro pontos amostrais, iniciando-se na nascente da cabeceira da bacia do Rio Cuiabá até a jusante da cidade de Barão de Melgaço. Os pontos escolhidos podem ser observados na Figura 1.

P1 - Cuiabazinho (próximo à área de nascente);

P4 - Passagem da Conceição;

P6 - Jusante do Córrego Ribeirão dos Cocais (avaliando a influência do Rio Coxipó);

P8 - Jusante de Barão de Melgaço.

Amostras de sedimento, foram constituída por sub-amostras com distribuição aleatória, realizadas com um amostrador do tipo raspador de fundo, sendo impossível representar profundidade devido ao amostrador ser do tipo raspador. Assim, em cada ponto amostral foram realizadas três coletas A, B e C o qual cada uma delas foi composta de três amostras simples (Costa, 2001).

\subsection{Análise física e química}

As análises de textura do sedimento empregado para designar a proporção relativa das frações argila, silte ou areia, que se diferenciam entre si pelo tamanho de suas partículas (granulometria). Para a dispersão das amostras de sedimento foram adicionados 25 gramas de solo peneirados em frascos, nestes foram colocados $50 \mathrm{ml}$ de água destilada; $10 \mathrm{ml}$ de $\mathrm{NaOH}$ a $6 \%$; em agitação em mesa agitadora por 16 horas. Em seguida completou o volume da proveta até $1000 \mathrm{ml}$ com água destilada este conteúdo com agitador manual por 30 vezes, a leitura da fração de areia e argila foi realizada pela técnica do densímetro de Bouyoucos, e a fração silte foi calculada por diferença (EMBRAPA, 1979).

As análises foram realizadas no laboratório de Física do Solo no Departamento de Engenharia Florestal da Universidade Federal de Mato Grosso, FAMEV. 


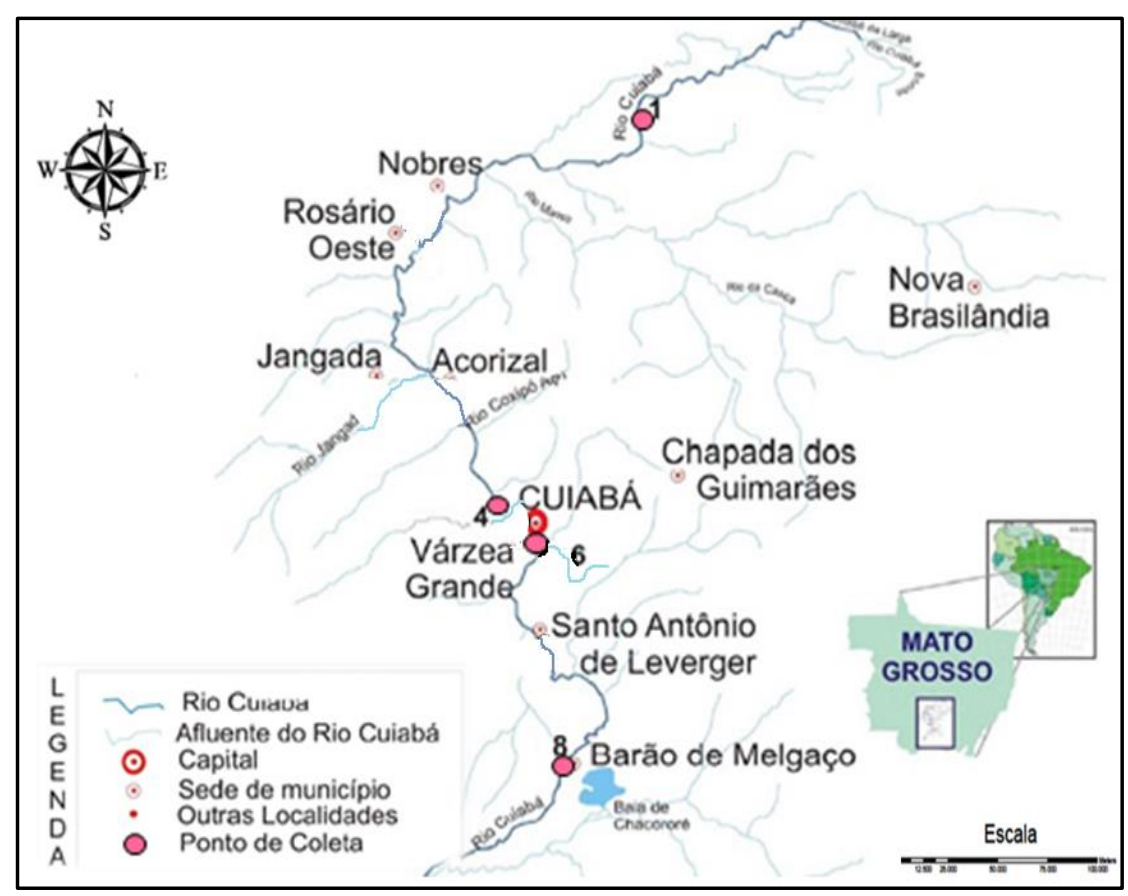

Figura 1. Localização das estações de amostragem de sedimento no rio Cuiabá.

\subsubsection{ANÁLISE QUÍMICA}

A concentração dos elementos químicos fósforo $(\mathrm{P})$, potássio $(\mathrm{K})$, matéria orgânica e potencial hidrogeniônico $(\mathrm{pH})$ das amostras foi determinada segundo as recomendações de EMBRAPA (1997).

As análises foram realizadas no laboratório de Fertilidade do Solo no Departamento de Engenharia Florestal da Universidade Federal de Mato Grosso, FAMEV.

\subsection{Processamento e quantificação bacteriana}

Para a quantificação bacteriana foram pesados $5 \mathrm{~g}$ de sedimento e adicionado em um Erlenmeyer contendo $45 \mathrm{~mL}$ de solução extratora adicionado de $1 \%$ de Tween 80 e $1 \%$ de pirofosfato de sódio, após etapa de agitação em mesa orbital a $220 \mathrm{rpm}$ por 30 minutos em temperatura ambiente. Após a homogeneização das amostras, foram retiradas uma alíquota de $1 \mathrm{~mL}$ desse material para iniciar as diluições seriadas necessárias para o processamento das amostras.As diluições $\left(10^{-2}\right.$ a $\left.10^{-6}\right)$ foram feitas em tubos de ensaio contendo $9 \mathrm{~mL}$ de solução salina $(0,85 \% \mathrm{NaCl})$ estéril (Neder, 1992). Para a quantificação de bactérias heterotróficas totais, foram inoculado $100 \mu \mathrm{L}$ das diluições $10^{-4}$ a $10^{-6}$, em triplicata, adicionado em meio TrypicSoy Agar (TSA), acrescentado de $0,04 \mathrm{~g} \mathrm{~L}^{-1}$ de ciclohexamida (fungicida), e para as bactérias fixadoras de nitrogênio foi realizado o mesmo processo citado acima, porém, inoculado em meios específicos e seletivos, que foram o meio NFB, JMV e Meio 79 segundo Döbereiner et al. (1999), e utilizando a técnica de Spread plate, as mesmas foram incubadas em estufa de crescimento por $35^{\circ} \mathrm{C}$ por $144 \mathrm{~h}$. Após a verificação do crescimento, foram realizadas contagens de unidades formadoras de colônia (UFC's) pelo método de Contagem Padrão em Placas (CPP) (Tortora et al., 2012).O número de colônias foi multiplicado pelo inverso do fator de diluição para obtenção do valor de UFC $\mathrm{mL}^{-1}$ de amostra e os valores expressos em Log de UFC $\mathrm{g}^{-1}$ de sedimento (Tortora et al., 2012).

\subsection{Caracterização Fenotípica}

Após a análise morfotintorial de Gram, foram realizados teste fisiológico e bioquímicas para todas as cepas selecionadas, a fim de caracterizar as estirpes fenotipicamente, uma prova a mais na identificação das bactérias isoladas. Os testes realizados foram; redução do nitrato, 
teste da catalase, teste de oxidação/fermentação de glicose e teste de Oxidase, e teste de motilidade segundo MacFaddin (1980).

\subsection{Análise estatística}

Os tratamentos estatísticos envolveram a análise descritiva para identificação de valores discrepantes, utilizando o teste não paramétrico de Kruskal-Wallis, pelo Software Statistica 7.0.

\subsection{Caracterização genotípica - BOX-PCR}

Para a extração do material genômico foi utilizado kit Genomic DNA fromTissueNucleoSpin ${ }^{\circledR}$ seguindo as instruções do fabricante.

Os fragmentos foram visualizados pela eletroforese em gel de agarose (Invitrogen) 0,5\% a 100 Volts por 30 minutos; o gel foi corado com brometo de etídio e foi usado um padrão de peso molecular $100 \mathrm{pb}$ e foi visualizada em um transluminador de luz UltraVioleta $(254 \mathrm{~nm})$. A avaliação da diversidade genética dos isolados bacterianos foi realizada usando a técnica Box-PCR, utilizando o primer Box-1AR ('5CTACGGCAAGGCGACGCTGACG-3') (Versalovic et al., 1994). A reação de amplificação foi realizada com os seguintes volumes: $12,5 \mu \mathrm{l}$ de $\mathrm{GoTaq}^{\circledR}$. A amplificação foi realizada usando os seguintes ciclos: um ciclo de desnaturação inicial a $95^{\circ} \mathrm{C}$ por $7 \mathrm{~min} ; 35$ ciclos de desnaturação $\left(1\right.$ min a $\left.94^{\circ} \mathrm{C}\right)$, anelamento $\left(1 \min\right.$ a $\left.53^{\circ} \mathrm{C}\right)$ e extensão $\left(8 \mathrm{~min}\right.$ a $\left.65^{\circ} \mathrm{C}\right)$; um ciclo de extensão final a $65^{\circ} \mathrm{C}$ por $16 \mathrm{~min}$; manutenção a $4^{\circ} \mathrm{C}$. Os fragmentos amplificados foram separados por eletroforese a $100 \mathrm{~V} \mathrm{em}$ gel de agarose a 2\%em tampão TAE 0,5 X. Após seis horas de corrida, o gel foi corado em brometo de etídeo e os fragmentos amplificados foram visualizados em transluminador UV $(254 \mathrm{~nm})$, assim como o produto da extração, para os amplificados também foi usado opadrão de peso molecular $100 \mathrm{pb}$.

O perfil de bandas geradas pela amplificação foram transformadas em dados binários (presença e ausência de bandas), e em seguida utilizadas para obter um dendrograma de similaridade calculado pelo coeficiente de Jaccard e agrupado utilizando o algoritmo UPGMA (UnweightedPair-GroupMethodwithArithmeticalAverage), utilizando o software Bionumerics 7.0 (AppliedMathematics, Kortrijk, Bélgica).

\section{RESULTADOS E DISCUSSÃO}

\subsection{Análise física e química}

A análise física por granulometria, para o teor de argila, silte e areia, nos pontos P1, P4, P6 e P8, da bacia do Rio Cuiabá, teve grande concentração de areia em todos os períodos de coleta, principalmente no Ponto P4 (Passagem da Conceição), localizado em um perímetro urbano, ponto muito conhecido por ser utilizado por banhista (ANA, 2011).

Todas as amostras apresentaram $\mathrm{pH}$ em torno cinco (5.0), essa acidez do sedimento pode ser devido as características do solo, que em sua maioria é lixiviado para a bacia. Como os solos da região são conhecidos por serem ácidos e de baixa fertilidade, necessitam de técnicas de calagem e adubação (Pereira et al., 1999).

Os resultados das análises químicas do sedimento para fósforo $(\mathrm{P})$, potássio $(\mathrm{K})$ e matéria orgânica (MO), e pH, foram caracterizados como sendo de maior relevância para o estudo proposto (Tabela 1). 
Tabela 1. Análises químicas referentes a pH, K, P e MO.

\begin{tabular}{|c|c|c|c|c|c|}
\hline \multirow[b]{2}{*}{ Coleta } & \multirow[b]{2}{*}{ Pontos amostrais } & \multicolumn{4}{|c|}{ Variáveis } \\
\hline & & $\underset{\left(\mathrm{CaCl}_{2}\right)}{\mathbf{p H}}$ & $\underset{\left(\mathbf{m g} / \mathbf{d m}^{3}\right)}{\mathbf{K}}$ & $\begin{array}{c}\mathbf{P} \\
\left(\mathbf{m g} / \mathbf{d m}^{3}\right)\end{array}$ & $\begin{array}{l}\text { MO } \\
(\%)\end{array}$ \\
\hline \multirow{4}{*}{$1^{\mathrm{a}}$} & $\mathrm{P} 1$ & 5,42 & 7,02 & 32,09 & 7,41 \\
\hline & $\mathrm{P} 4$ & 5,48 & 2,92 & 26,82 & 1,53 \\
\hline & P6 & 5,51 & 4,81 & 46,62 & 2,62 \\
\hline & P8 & 6,10 & 6,05 & 33,46 & 1,98 \\
\hline \multirow{4}{*}{$2^{\mathrm{a}}$} & $\mathrm{P} 1$ & 5,52 & 173,89 & 26,06 & 62,85 \\
\hline & $\mathrm{P} 4$ & 6,28 & 138,07 & 23,62 & 134,24 \\
\hline & P6 & 5,87 & 131,56 & 46,80 & 205,61 \\
\hline & P8 & 6,01 & 149,14 & 28,90 & 121,38 \\
\hline \multirow{4}{*}{$3^{a}$} & $\mathrm{P} 1$ & 6.6 & 4,22 & 24,86 & 2,78 \\
\hline & P4 & 5,78 & 7,14 & 30,28 & 3,41 \\
\hline & P6 & 4,73 & 5,36 & 59,85 & 4,35 \\
\hline & P8 & 5,31 & 7,40 & 35,16 & 3,95 \\
\hline \multirow{4}{*}{$4^{\mathrm{a}}$} & $\mathrm{P} 1$ & 5,84 & 9,21 & 37,81 & 5,19 \\
\hline & $\mathrm{P} 4$ & 5,54 & 7,00 & 29,89 & 4,64 \\
\hline & P6 & 5,90 & 9,98 & 34,62 & 8,45 \\
\hline & P8 & 5,80 & 13,40 & 39,54 & 6,10 \\
\hline \multirow{4}{*}{$5^{\mathrm{a}}$} & $\mathrm{P} 1$ & 5,81 & 8,01 & 31,95 & 4,76 \\
\hline & $\mathrm{P} 4$ & 5,64 & 7,10 & 23,14 & 4,95 \\
\hline & P6 & 5,43 & 8,44 & 35,10 & 7,78 \\
\hline & P8 & 5,33 & 14,67 & 22,77 & 6,47 \\
\hline \multirow{4}{*}{$6^{a}$} & $\mathrm{P} 1$ & 5,04 & 7,29 & 32,50 & 4,84 \\
\hline & P4 & 5,79 & 8,29 & 27,41 & 4,54 \\
\hline & P6 & 5,07 & 4,57 & 67,09 & 3,02 \\
\hline & P8 & 6,10 & 11,38 & 35,40 & 10,67 \\
\hline
\end{tabular}

Em relação as análise de fósforo, potássio e matéria orgânica, verificou-se pouca variação em relação os pontos de coleta. Contudo uma variação entre os meses de coleta foi observada, principalmente referentes as análises de potássio e matéria orgânica.

E esse valor referenciado do fósforo, bem como do potássio, pode ser reflexo das práticas agrícolas na bacia, e segundo Rheinheimer et al. (2003) são vistos como uma importante fração presentes nos solos erodidos e está fortemente associada aos minerais de argila, e as práticas de fertilização dos solos.

Os valores de matéria orgânica podem ser evidenciados devido a uma maior atividade bacteriana. Visto que no trabalho realizado por Xavier et al. (2006), a utilização preferencial de diferentes componentes da matéria orgânica por certo grupos de bactérias, pelo seu metabolismo da comunidade, é sempre acompanhado pelas mudanças na sua composição. E sabe-se que as alterações que ocorrem no sistema aquático são reflexos em parte dos impactos sofridos pelo ecossistema terrestre, sendo os sedimentos um importante elo entre esses dois sistemas (Minella et al., 2007).

\subsection{Caracterização Microbiológica}

Avaliando o crescimento bacteriano de heterotróficos totais em meio TSA e bactérias fixadoras de nitrogênio crescidas nos meios 79, NFB e JMV incubados por 144 horas, verificou-se, que não houve grandes variações por pontos amostrais como verificado nas Figuras 2, 4, 6 e 8. Porém em relação ao tempo, foi possível verificar uma variação representativa entre os meses amostrados conforme Figuras 3, 5, 7 e 9. 


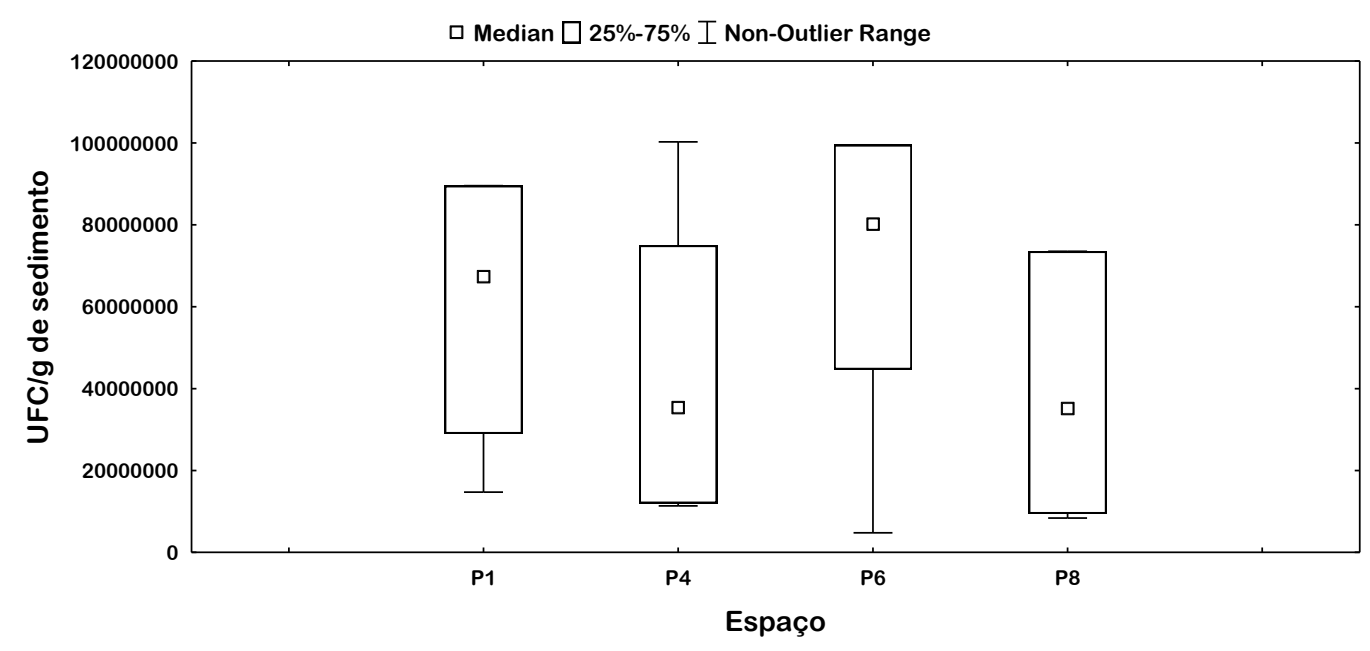

Figura 2. Representação gráfica do Box-plot para análise do meio TSA $(\mathrm{KW}-\mathrm{H}(3 ; 24)=1.78 ; \mathrm{p}=0.6193)$.

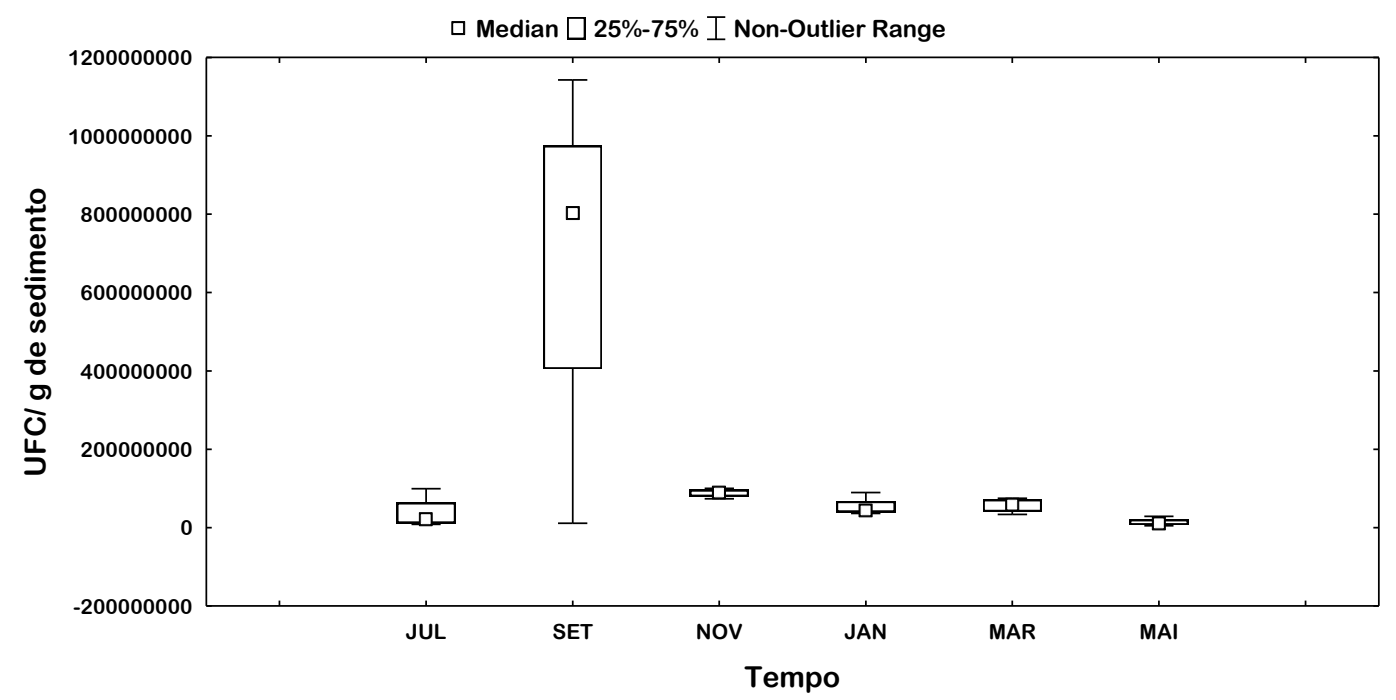

Figura 3. Representação gráfica do Box-plot para análise do meio TSA (KW-H(5;24) $=11,66 ; \mathrm{p}=0,0398)$.

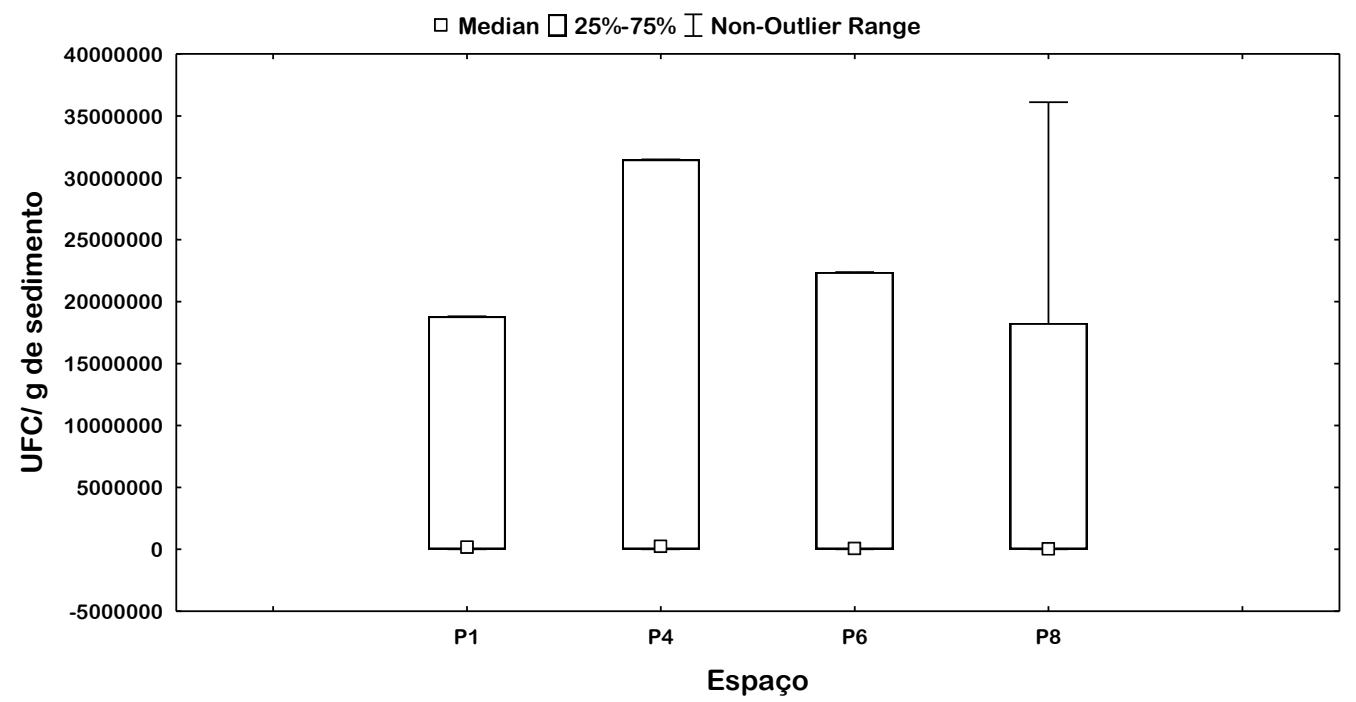

Figura 4. Representação gráfica do Box-plot para análise do meio JMV: $\mathrm{KW}-\mathrm{H}(3 ; 24)=0,2422 ; \mathrm{p}=0,9705$. 


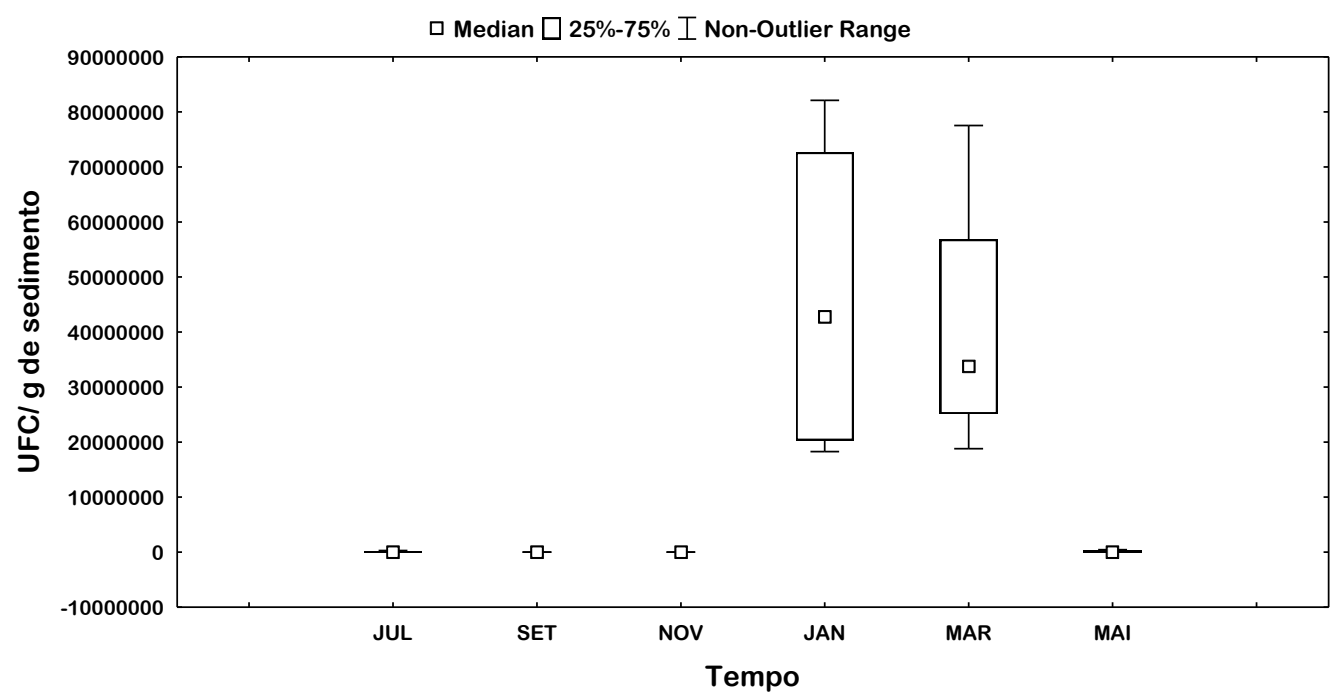

Figura 5. Representação gráfica do Box-plot para análise do meio JMV (KW$\mathrm{H}(5 ; 24)=21,2978 ; \mathrm{p}=0,0007$.

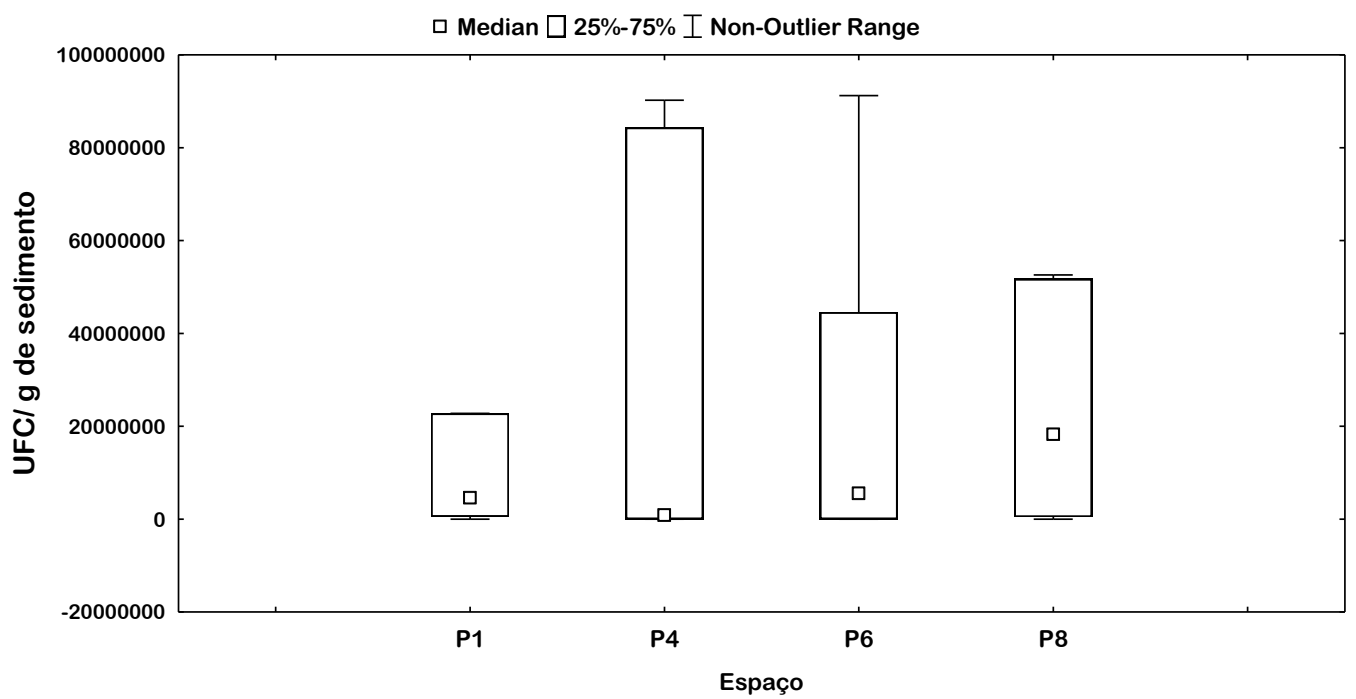

Figura 6. Representação gráfica do Box-plot para análise do meio 79 (KW-H(3;24) = 0,$1269 ; \mathrm{p}=0,9884$.

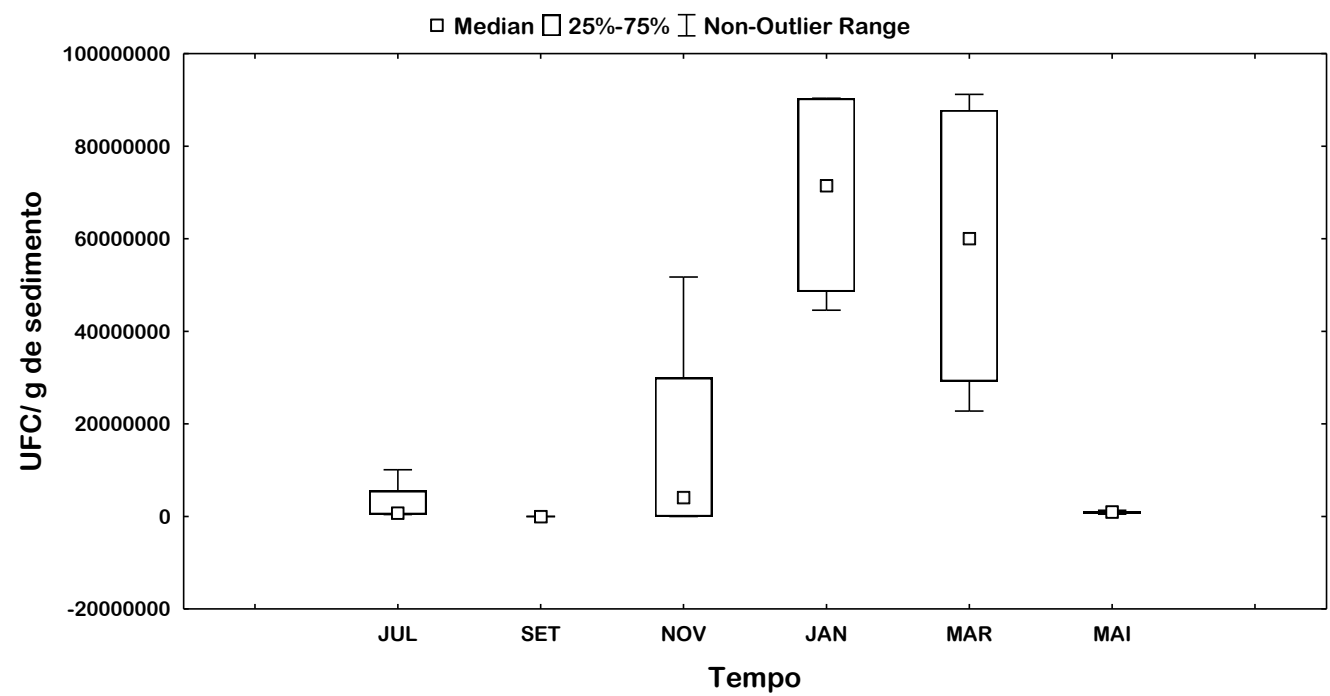

Figura 7. Representação gráfica do Box-plot para análise do meio 79 (KW-H(5;24) $=17,1916 ; \mathrm{p}=0,0042)$. 


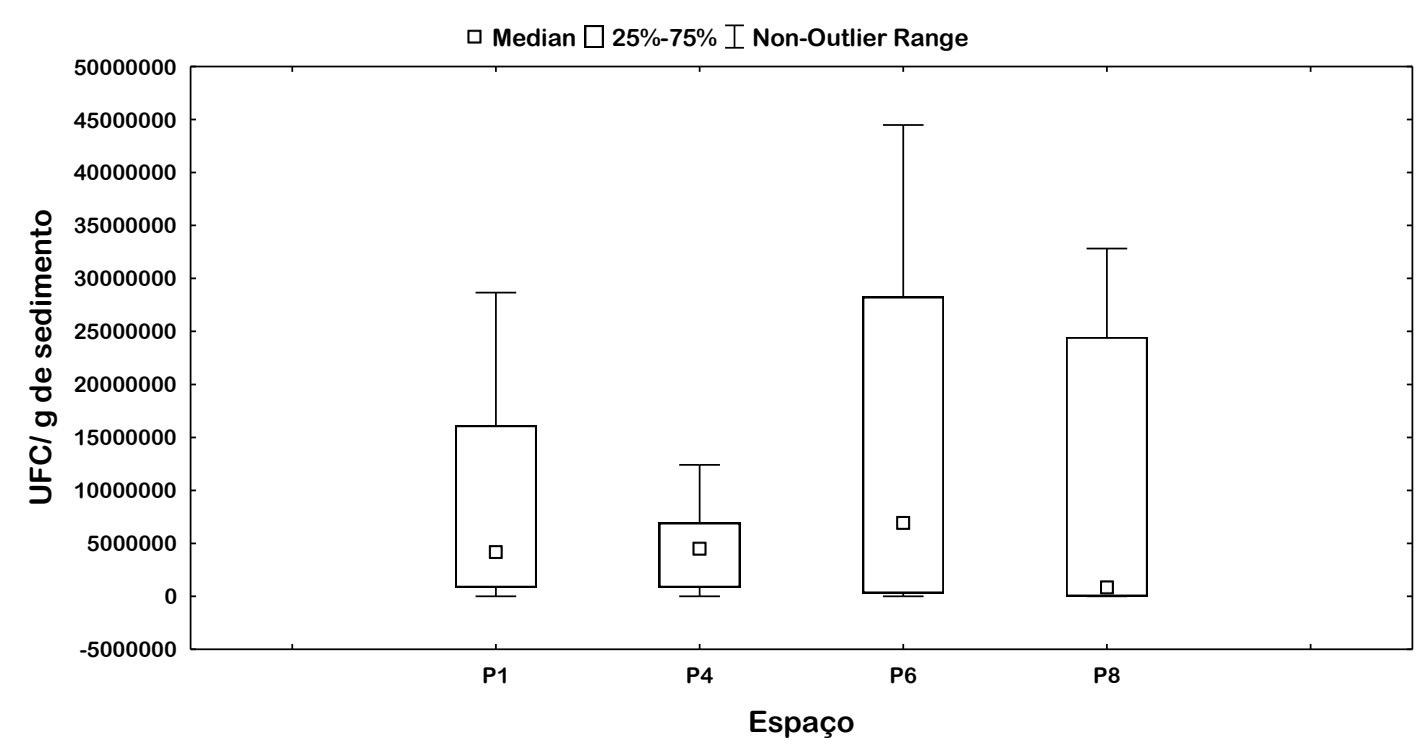

Figura 8. Representação gráfica do Box-plot para análise do meio NFB $(\mathrm{KW}-\mathrm{H}(3 ; 24)=$ 0,$6523 ; p=0,8844$.

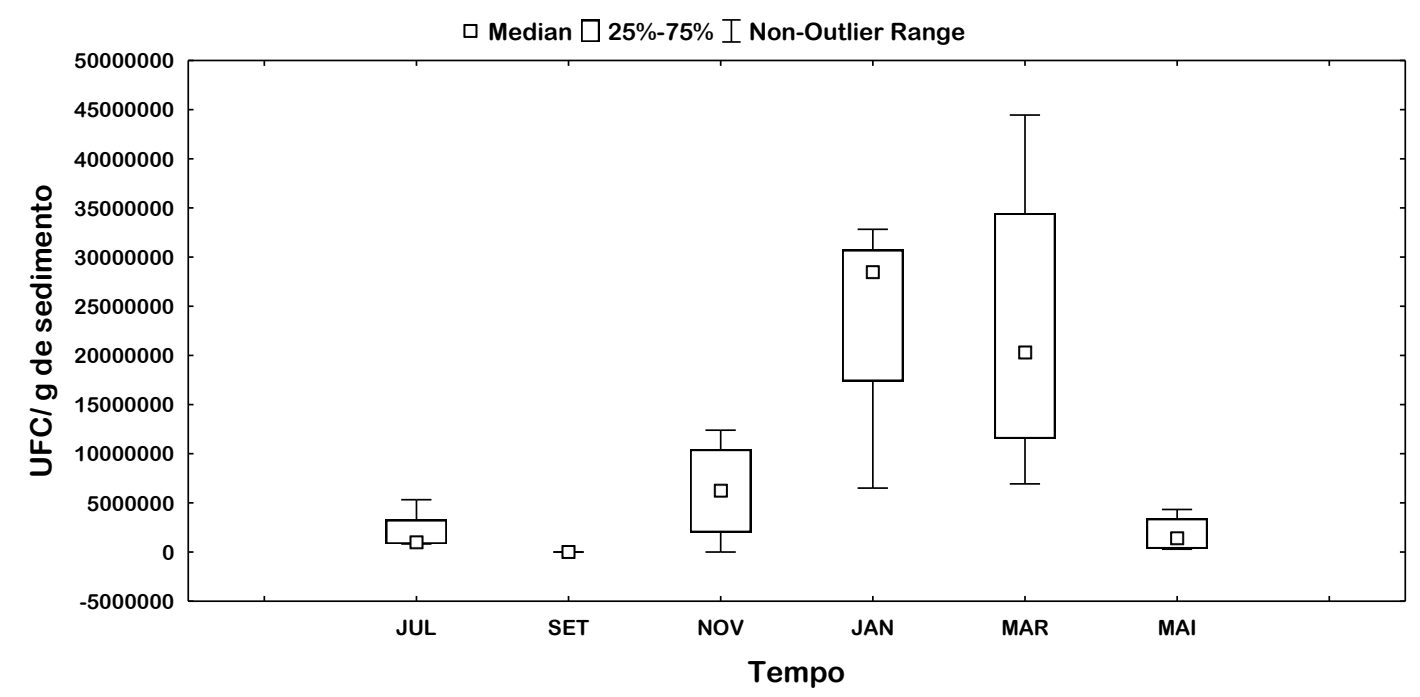

Figura 9. Representação gráfica do Box-plot para análise do meio NFB: KW-H(5;24) = 17,$6333 ; p=0,0034$.

De acordo com os resultados apresentados, pode-se inferir que o rio ainda possui capacidade de autodepuração, restabelecendo o equilíbrio, após as alterações induzidas pelos despejos efluentes. Segundo Von Sperling (2005) e Andrade (2010) a autodepuração é um processo natural, no qual cargas poluidoras, de origem orgânica lançadas em um corpo d'água são neutralizadas, pela decomposição da matéria orgânica por micro-organismos aeróbios.

Conforme já observado por Vrede (2005), variações na temperatura e nos nutrientes inorgânicos e orgânicos podem limitar a atividade e a abundância bacteriana. A quantidade e a qualidade da matéria orgânica do sedimento tem sido consideradas como os principais fatores determinantes na estruturação da comunidade microbiana (Haglund et al., 2003).

Segundo Tammert et al. (2008) e Reis et al. (2008), mudanças na concentração de importantes fatores ambientais podem provocar o desequilíbrio na comunidade microbiana, podendo inibir determinadas populações de micro-organismos e estimular outras populações insensíveis ao composto. 
Os resultados indicam que o rio possui capacidade de autodepuração e de restabelecimento do equilíbrio após as alterações induzidas pelos despejos de efluentes.

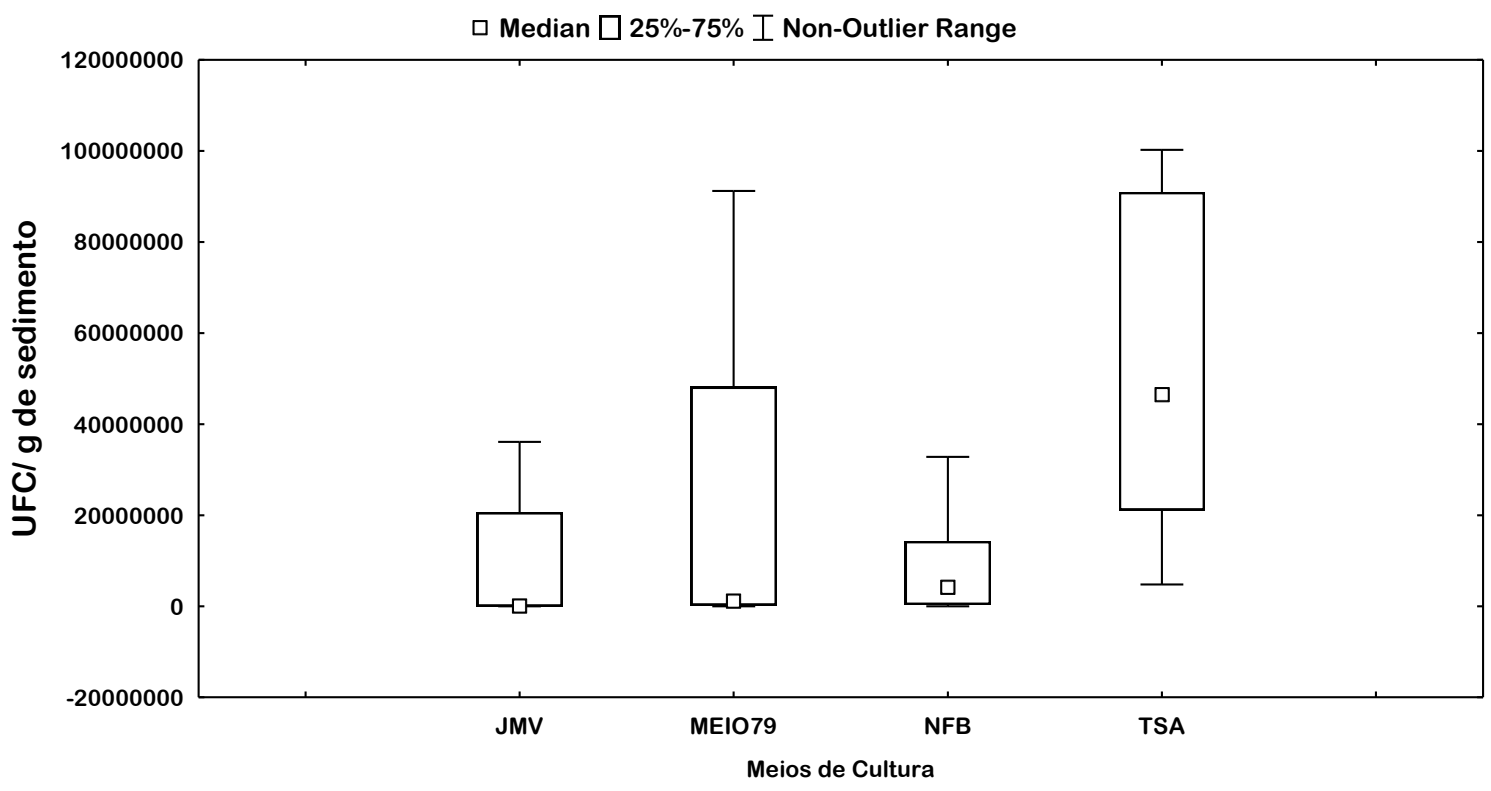

Figura 10. Representação gráfica do Box-plot para análise da densidade entre os meios $(\mathrm{KW}-\mathrm{H}(3 ; 96)=28,3608 ; \mathrm{p}=0,0003)$.

É possível observar na Figura 10 que no meio TSA, o crescimento bacteriano foi melhor representado, e isso pode ser devido ao fato do meio não ser tão seletivo e facilitar o crescimento de bactérias heterotróficas. Porém, não é o mesmo que ocorre nos meios 79, NFB e JMV como observados na Figura 10, que por serem meios específicos para bactérias fixadoras de nitrogênio, não apresentaram um crescimento representativo, em comparação aos meios utilizados. Conforme Döbereiner et al. (1999) os meios 79, NFB e JMV são utilizados para manutenção e isolamento de bactérias fixadoras de nitrogênio do gênero Rhizobium, Azospirillum spp e Burkholderia brasilensis, respectivamente.

A análise morfotintorial de Gram permitiu caracterizar as bactérias processadas de acordo com o tipo de Gram e forma celular. A maioria dos isolados, 59\%, pertencem ao grupo de bastonetes positivos, o que já era previsto, segundo a literatura, devido aos microorganismos pertencentes a este grupo, serem mais resistentes as diversidades bióticas encontradas, como temperatura, disponibilidade de nutrientes, bem como a presença de contaminantes (Tortora et al., 2012).

É possível se verificar com a análise de Gram a presença de endósporos na maioria nos bastonetes Gram-positivos. Em grande parte dos isolados ambientais, principalmente em bactérias do gênero Bacillus e Clostridium, que por uma visão filogenética, a capacidade de produzir endósporos está ligada exclusivamente a uma sublinhagem particular de bactérias Gram-positivas. Apesar disso, a fisiologia das bactérias formadoras de endósporos é bastante diversa, incluindo anaeróbicos, aeróbicos, fototróficos e quimiolitotróficos (Daniel, 1999; Madigan et al., 2004).

Segundo Van Elsas et al. (1998), a limitação da produção bacteriana por diferentes elementos pode acarretar alterações tanto na forma quanto no tamanho bacteriano, e então desconfigurar padrões de forrageiro sobre a bactéria e, por consequência, modificar a estrutura da comunidade bacteriana.

Uma vez que não existe uma chave de identificação bacteriológica para amostras ambientais, foi utilizado o BiochemicalTests for Identificationof Medial Bacteria (MacFaddin, 1980), bem como literatura de Vermelho et al. (2006). 
Assim, por meio dos testes bioquímicos pôde-se identificar as bactérias apenas em nível de família, sendo identificadas treze famílias, algumas presentes em todas as coletas como a família Bacillaceae com 28\%, seguido da família Corynebacteriaceae com 14\%, e da família Propionibacteriaceae com 12\%, e ainda das famílias Micrococcaceae representando $11 \%$ e a família Peptococcaceae com $9 \%$, e $14 \%$ dos isolados foram classificados como não determinados.

Visto que as coletas foram realizadas nos períodos de chuva e seca, e sabe- se que a distribuição da abundância bacteriana está estreitamente relacionada às propriedades do sedimento, bem com as mudanças no fluxo de nutrientes, podemos inferir que os resultados possam estar relacionados com as variações sazonais e outras mudanças ambientais (Carvalho e Paranhos, 2010).

\subsection{Caracterização genotípica- BOX-PCR}

Dentre as 202 colônias identificadas, foram processadas 32 isolados nos testes genéticos. A redução se deve à equalização do esforço de amostragem por período de coleta e pelos testes bioquímicos, tendo em vistaa exclusão de amostras nas quais houve provável contaminação durante o isolamento da colônia, e as cepas de interesse para esta análise foram da família Bacillaceae.

Os perfis de bandas (Figura 11) obtidos para os diferentes isolados pela técnica de BOXPCR foram analisados e o dendograma de similaridade foi construído.
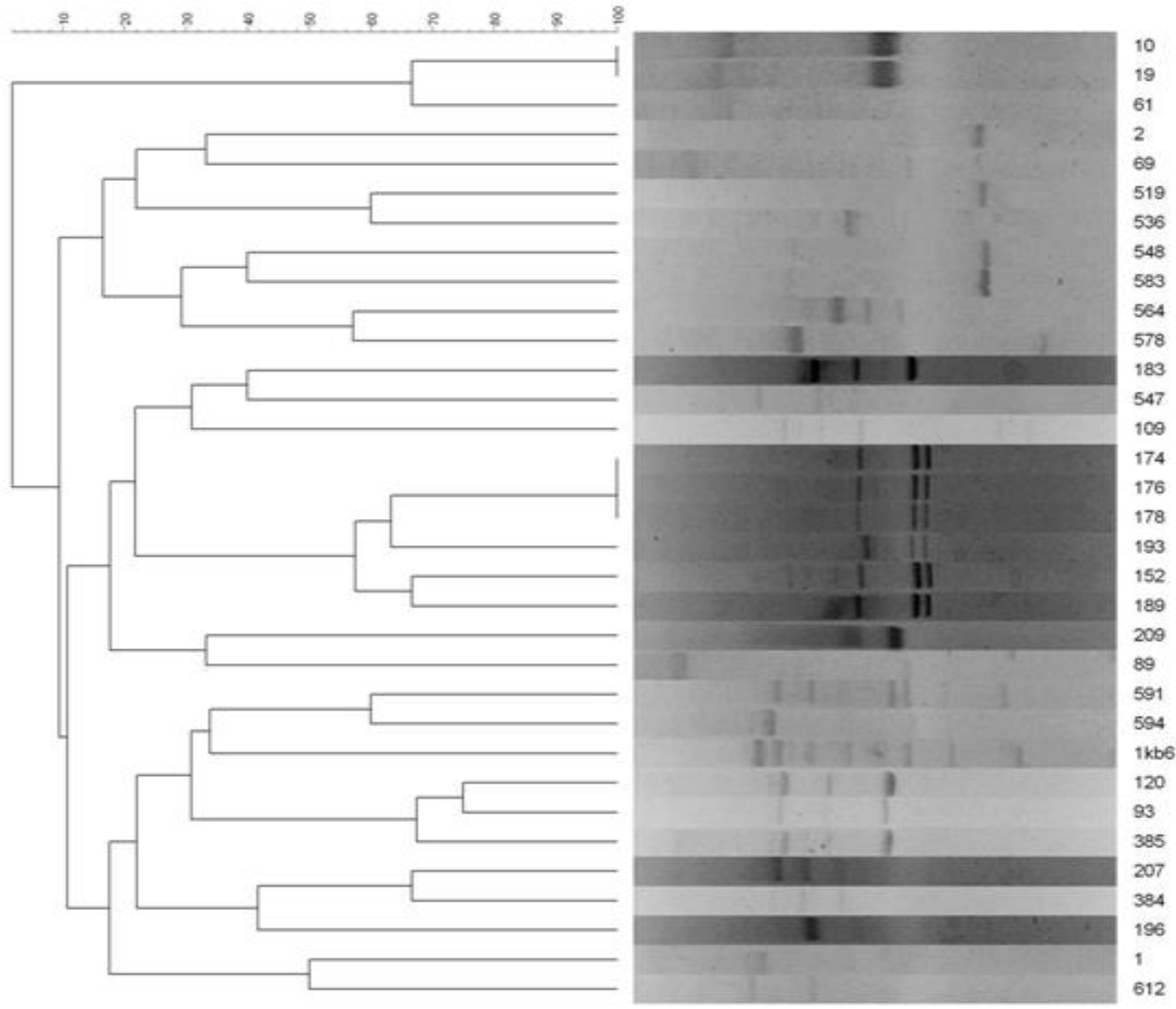

Figura 11. Dendograma de similaridade genética construído com o índice de Jaccard e método de agrupamento UPGMA, mostrando agrupamentos formados entre os isolados analisados pela técnica BOX-PCR. 
Os dados obtidos das amostras ambientais refletem a diversidade da comunidade e as diferenças detectadas entre os locais de amostragem, de acordo com a análise do BOX-PCR. Os resultados estão de acordo com a literatura, os quais apontam que a variabilidade da comunidade bacteriana é influenciada pelos diferentes tipos de micro-ambiente existente em cada tipo de sedimento (Haglud et al., 2003; Pace e Prairie, 2004).

Assim, as cepas 10 e 19 obtidos de pontos amostrais diferentes, sendo a cepa 10 do ponto 6 (Ribeirão dos Cocais) e a cepa 19 do ponto 8 (Barão de Melgaço), possuindo $100 \%$ de similaridade, observou-se ainda que a cepa 61 teve $65 \%$ de similaridade com os isolados 10 e 19 , sendo esta do ponto 6 , sendo os mesmos, isolados da primeira coleta.

Já as cepas 174, 176, 178 e 193, apresentaram 100\% de similaridade, porém as cepas 174 e 178 pertencem ao mesmo espaço amostral, o ponto 8, já a cepa 176 pertence ao ponto 1 (Cuiabazinho) e a cepa 193 ao ponto 6, ambas isoladas da terceira coleta. E as cepas 93 ponto 1 e 120 ponto 6 apresentaram $70 \%$ de similaridade.

As demais estirpes apresentaram uma dissimilaridade com alta diversidade genética, esses dados podem confirmar a capacidade de autodepuração do rio, uma vez que ainda há uma variabilidade bacteriana, possibilitando a biodegradação de possíveis poluentes.

Holguin et al. (2001) e Melloni et al. (2006) mencionam que estudos de diversidade microbiana são importantes, pois relaciona a variabilidade genética, bem como verifica a distribuição ecológica dos mesmos.

Assim, o uso de técnicas moleculares deve ser estimulado devido ao desenvolvimento de métodos simples e rápidos para a caracterização de populações microbianas, inclusive para estudos em nível de gênero e espécie (Kirk et al., 2004).

\section{CONCLUSÃO}

Com base em técnicas convencionais de microbiologia, foi possível quantificar e verificar a diversidade bacteriana ao longo do gradiente, observando uma maior quantificação de bactérias heterotróficas, observada no meio TSA, ao longo do gradiente amostral. Porém, a utilização de meios específicos não propôs resultados satisfatórios, devido ao fato de ter encontrado bactérias com as mesmas características tanto morfológicas quanto fisiológicas nestes meios, e suas características e composição deveriam ser mais seletivos.

As análises bioquímicas mostraram uma diversidade significativa das famílias bacterianas, principalmente da Bacillaceae, formada por bacilos esporulados.

A análise molecular por BOX-PCR mostrou ser uma técnica molecular eficiente, uma vez que é uma técnica rápida, de fácil execução e altamente discriminatória, verificando uma diversidade genética da comunidade bacteriana, obtendo uma riqueza de espécies entre os pontos amostrais, observando que a bacia do rio Cuiabá, ainda apresenta características de autodepuração, apesar de em alguns pontos apresentarem atividades agro-industriais.

\section{REFERÊNCIAS}

AGÊNCIA NACIONAL DAS ÁGUAS - ANA (Brasil). Relatório final: avaliação dos mecanismos financeiros para o gerenciamento sustentável da bacia piloto do rio Cuiabá. ANA/GEF/PNUMA/OEA. Brasília, 2003.

AGÊNCIA NACIONAL DAS ÁGUAS - ANA (Brasil). Guia nacional de coleta e preservação de amostras-água, sedimento, comunidades aquáticas e efluentes líquidos. Brasília, 2011.

ANDRADE, L. N. Autodepuração dos corpos d'água. Revista da Biologia, v. 5, Dez. 2010. 
BEGON, M.; TOWNSEND, C. R.; GARPER, J. L. Ecologogy: from individuals to ecosystems. 4. ed. Liverpool: School of Biological Sciences, The University of Liverpool, 2006. 765p.

CALHEIROS, D. F. Determinação de impactos e conservação dos recursos hídricos na bacia do Alto Paraguai. 2008. In: Disponível em : http://www.agronline.com.br/ artigos/artigo.php?id=310. Acesso em: 10 maio 2011.

CARVALHO, K. D. C.; PARANHOS, R. Análise de abundância bacteriana no estudo da ecologia microbiana de sedimentos marinhos. Oecologia Australis, v. 14, n. 2, p. 415436, jun. 2010. http://dx.doi.org/10.4257/oeco.2010.1402.06

COSTA, R. S. Variabilidade e diversidade genética de comunidades bacterianas associadas a rizosfera de milho (Zeamays L. Merril) em um agrossistema do Rio de Janeiro. 2001. 127 p. Dissertação (Mestrado) - Universidade Federal do Rio de Janeiro, Rio de Janeiro, 2001.

CUIABÁ. Secretaria do Meio Ambiente. Relatório de monitoramento da qualidade das águas da sub-bacia do Rio Cuiabá/MT. Cuiabá, 2005.

DANIEL, R. C. Microbial physiology and metabolism. 2. ed. Star Publishing, 1999.

DÖBEREINER, J.; ANDRADE, V. O.; BALDANI, V. L. D. Protocolos para preparo de meios de cultura da Embrapa Agrobiologia. Seropédica: EMBRAPA, 1999.

EÇA, L. P. M. Biologia molecular: apresentação de algumas técnicas utilizadas na biologia molecular. Revinter, 2004. p.145-155.

EMPRESA BRASILEIRA DE PESQUISA AGROPECUÁRIA - EMBRAPA. Centro Nacional de Pesquisa de Soja. Ecologia, manejo e adubação da soja. Londrina, 1979. (Circular técnica, 2)

EMPRESA BRASILEIRA DE PESQUISA AGROPECUÁRIA - EMBRAPA. Centro Nacional de Pesquisa de Solos. Manual de métodos de análise de Solo. 2. ed. Seropédica, 1997.

GIMENES, K. Z.; CUNHA-SANTINO, M. B.; BIACHINI JR., I. Decomposição de matéria orgânica alóctone e autóctone em ecossistemas aquáticos. Revista Oecologia Australis, v. 14, n. 4, p. 1036-1073, dez. 2010. http://dx.doi.org/10.4257/oeco.2010.1404.13

HAGLUND, A. L.; LANTZ, P.; TORNBLOM, E.; TRANVIK, L. Depth distribution of active bacteria and bacterial activity in lake sediment. FEMS Microbiology Ecology, 46. p. 31-38, 2003. http://dx.doi.org/10.1016/S0168-6496(03)00190-9

HOLGUIN, G.; VAZQUEZ, P.; BASHAN, Y. The role of sediment microorganisms in the productivity, conservation, and rehabilitation of mangrove ecosystems: an overview.

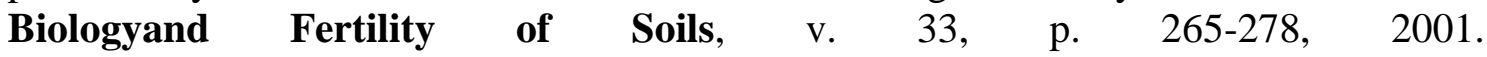
http://dx.doi.org/10.1007/s003740000319

KIRK, J.; BEAUDETTE, L.; HART, M.; MOUTOGLIS, P. Methods of studying soil microbial diversity. Journal of Microbiological Methods, v. 58, p. 169-188, 2004. http://dx.doi.org/10.1016/j.mimet.2004.04.006

MACFADDIN, J. F. Biochemical tests for identification of medical bacterial. 2. ed. Baltimore : Williams \& Wilkins, 1980. 
MADIGAN, M. T.; MARTINKO, J. M.; PARKER, J. Microbiologia de Brock. 10. ed. São Paulo: Pearson; Prentice Hall, 2004.

MELlONI, R. R.; NÓBREGA, S. A.; MOREIRA F. M. S.; SIQUEIRA J. O. Densidade e diversidade fenotípica de bactérias diazotróficas endofíticas em solos de mineração de bauxita, em reabilitação. Revista Brasileira Ciência do Solo, v. 28, v. 1, p. 85-93, 2006. http://dx.doi.org/10.1590/S0100-06832004000100009

MINELLA, J. P. G.; MERTEN, G. H.; REICHERT, J. M.; SANTOS, D. R. Identificação e implicações para a conservação do solo das fontes de sedimentos em bacias hidrográficas. Revista Brasileira Ciência do Solo, v. 31, n. 6, p. 1637-1646, 2007. http://dx.doi.org/10.1590/S0100-06832007000600039

NEDER R. N. M. Microbiologia: manual de laboratório. São Paulo: Nobel, 1992. 138p.

ODUM H. T. Environment, power and society for the twenty-first century: the hierarchy of energy. New York: Columbia University Press, 2007. 432p.

PACE, M. L.; PRAIRIE, Y. T. Respiration in aquatic ecosystems: respiration in lakes. Oxford: Oxford University Press, 2004.

PERREIRA, J. C.; NEVES, M. C. P.; DROZDOWICZ. Dinâmica das populações bacterianas em solos de cerrados. EMBRAPA, v. 34, n. 5, p. 801-811, maio 1999.

REIS, M. R.; SILVA, A. A.; COSTA, M. D.; GUIMARÃES, A. A.; FERREIRA, E. A. SANTOS, J. B. et al. Atividade microbiana em solo cultivado com cana-de-açúcar após aplicação de herbicida. Planta Daninha, Viçosa-MG, v. 26, n. 2, p. 323-331, 2008.

REIS JUNIOR, F. B. R.; MENDES, I. C.; TEIXEIRA, K. R. S. REIS, V. M. Uso de ferramentas moleculares em estudos da diversidade de micro-organismos do solo. Planaltina: EMBRAPA, 2002.

RHEINHEIMER, D. S.; ANGHINONI, I.; CONTE, E. Sorção de fósforo em função do teor inicial e de sistemas de manejo de solos. Revista Brasileira de Ciências do Solo, v. 27, n. 1, p. 41-49, 2003. http://dx.doi.org/10.1590/S0100-06832003000100005

SHINMA, E. A. Avaliação da qualidade das águas dos rios da Bacia Hidrográfica do Alto Paraguai-Pantanal. 2004. Dissertação (Mestrado) - Universidade do Mato Grosso do Sul, Campo Grande, 2004.

TAMMERT, H.; OLLI, K.; STURLUSON, M.; HODAL, H. Bacterial biomass and activity in the marginal ice zone of the northern Barents Sea. Deep-Sea Research Part II: Tropical Studies in Oceanography, v. 55, p. 2199-2209, 2008. http://dx.doi.org/10.1016/j.dsr2.2008.05.011

TORTORA, G. J.; FUNKE, B. R.; CASE, C. L. Microbiologia. 10. ed. Porto Alegre: Artemed, 2012.

VAN ELSAS, J. D.; DUARTE, G. F.; ROSADO, A. S.; SMALLA, K. Microbiological and molecular biological methods for monitoring microbial inoculants and their effects in the soil environment. Journal of Microbiological Methods, v. 32, n. 2, p. 133-154, 1998. http://dx.doi.org/10.1016/S0167-7012(98)00025-6

VERMElHO, A. B.; COELHO, R. R. R.; PEREIRA, A. F. Práticas de microbiologia. Rio de Janeiro: Gaunabara Koogan, 2006. 
VERSALOVIC, J.; SCHNEIDER, M.; BRUIJN, F. J.; LUPSKIW, J. R. Genomic fingerprinting of bacteria using repetitive sequence-based polymerase chain reaction. Methods in Molecular and Cellular Biology, v. 5, p. 25-40, 1994.

VON SPERLING, M. Princípios do tratamento biológico de águas residuárias. 3. ed. Belo Horizonte: Departamento de Engenharia Sanitária e Ambiental/UFMG, 2005.

VREDE, K. Nutrient and temperature limitation of bacterioplankton growth in temperate lakes. Microbial Ecology, v. 49, p. 245-256, 2005. http://dx.doi.org/10.1007/s00248004-0259-4

XAVIER, F. A. S.; MAIA, S. M. F.; OLIVEIRA, T. S.; MENDONÇA, E. S. Biomassa microbiana e matéria orgânica leve em solos sob sistemas agrícolas orgânico e convencional na Chapada da Ibiapaba-CE. Revista Brasileira de Ciência do Solo, v. 30, p. 247-258, 2006. http://dx.doi.org/10.1590/S0100-06832006000200006 